\title{
Exploring Chemistry Teachers' General Pedagogical Knowledge through Teachers' Self-reflection
}

\author{
Rufino Trinidad-Velasco ${ }^{1}$, Flor Reyes-Cárdenas ${ }^{2 *}$ \\ ${ }^{1}$ Department of Chemistry, Institute of Upper Middle Education, Mexico City, Mexico, ${ }^{2}$ Department of Inorganic and Nuclear Chemistry, Faculty of \\ Chemistry, National Autonomous University of Mexico, Mexico City, Mexico
}

*Corresponding Author: florreyes@gmail.com

\section{ABSTRACT}

A characterization of the teaching of three chemistry professors was carried out using a case study with a phenomenographic approach to explore chemistry teachers' general pedagogical knowledge (GPK) through teachers' self-reflection. A video stimulated recall technique was used to identify and examine teachers' thoughts and decisions, as well as the reasons for driving their behavior. The results showed that these teachers concentrated most of their GPK in eight categories, three of them reported in the literature with the highest frequencies. This could indicate that GPK emerged in different facets depending on the institutional context, and therefore, their teaching experience. This study also identifies three new categories of GPK not reported before: Applying learned concepts and abilities, student-student interaction, and assessment. Therefore, a new perspective on pedagogical content knowledge research is open that will lead us to future research.

KEY WORDS: general pedagogical knowledge; teacher knowledge base; teacher education; chemistry teaching; general pedagogical knowledge

\section{INTRODUCTION}

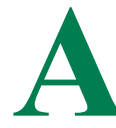

quality education requires teachers with good teaching practices; this will require a good level of disciplinary knowledge and a set of aspects that are necessary to teach students what they need (Peterson et al., 1992).

Teachers with broad and deep basic professional knowledge can offer their students a wider range of learning opportunities. Shulman (1986) provide three basic teacher's knowledge dimensions: (1) Content knowledge (CK) is a disciplinerelated knowledge; (2) pedagogical $\mathrm{CK}$ (PCK) is related to the ability to explain a specific topic to the students, this knowledge goes beyond the knowledge of the discipline and refers to "disciplinary knowledge for teaching" (p. 9); and, (3) general pedagogical knowledge (GPK) related to the nature of learning, its processes, and the teaching methods; regardless of discipline. These three dimensions are what have had the most influence on research into teacher knowledge (Baumert et al., 2010; Kirschner et al., 2016; Lachner et al., 2016; König et al., 2017).

Some researchers have raised the question of whether GPK and PCK are related to each other or whether they can be separated. Recently, König et al. (2018) conducted research to address this question with Mathematics, German, and English teachers. Their findings show that GPK and PCK can be empirically separated, as they can be registered using knowledge tests that allow them to be distinguished as separate categories of knowledge.
High-quality teaching allows teachers to offer highly efficient learning opportunities that will help improve student performance. To determine the quality of teaching that drives student progress and motivational development, there are three important aspects: Knowledge on the specific domain, pedagogical knowledge in general, and teaching skills (Baumert et al., 2010). Therefore, teachers require "an intellectual framework" to organize their classrooms. In other words, teachers require knowledge on concepts, principles, and pedagogical techniques that are not part of the discipline's content (Shulman, 1987; Grossman, 1990; Borko and Putnam, 1996; König, 2014).

The teaching approach is a powerful predictor of how much students will learn (Peterson et al., 1992). The quality of teaching can be improved by creating an effective learning environment (Voss et al., 2011). Teaching is conceptualized as a complex activity in which teachers participate; they are always carrying out actions, generating ideas, and decisions that lead them to choose their role as instructors, through the complex use of knowledge networks, thoughts and beliefs, established with a practical and personalized sense and within their context (Akbari and Tajik, 2009; Guerriero and Deligiannidi, 2017).

Many researchers have focused on the first two knowledge basic dimension (CK and PCK), and GPK has been somehow neglected, although recent research has shown that it is as important as CK and PCK (Guerriero, 2017). In recent years, some studies on the GPK have been carried out in different 
contexts (König, 2014; Sonmark et al., 2017; König et al., 2017). Baumert et al. (2010), Garrahy et al. (2005), König et al. (2011), and Voss et al. (2011) concur that it remains unclear how GPK contributes to a teacher's knowledge base. However, lately, new studies on GPK (Kirschner et al., 2016; Lachner et al., 2016) have emerged, and the conceptualization of GPK is now more precise and robust. Gatbonton (1999; 2008), Mullock (2006) and König et al. (2011; 2014) focused their research on GPK with teachers of second language and mathematics. These studies, however, do not include other disciplines, like chemistry.

Knowledge documentation of teachers (experts and learners) can help to create learning goals and guidelines to improve curricular programs in teacher training and in consequence, to design and implement training courses to update their knowledge (König, 2014). For the above, it is essential to study how teachers express themselves about their lessons and their practices to aim students learning in. As a result, this study's purpose was:

To explore, describe, and identify the most relevant aspects of the GPK of three chemistry teachers with different formal teaching education.

\section{LITERATURE REVIEW: GPK}

GPK involves "principles and strategies of classroom management and organization that appear to transcend subject matter" (Shulman, 1987. p. 8). According to Morine-Dershimer and Kent (1999), this limited outlook of GPK could be a side effect of Shulman's concern regarding the re-establishment of the content as a critical phase of teacher's knowledge; and a contextual feature often ignored in current classroom's research work.

Shulman's idea is extended in later conceptualizations, to include knowledge about aspects of teaching methods, students' motivation, student heterogeneity, and evaluation. Furthermore, Grossman (1990) states that GPK comprises a body of general knowledge, beliefs, and skills related to teaching and learning (knowledge and beliefs about learning and learners); knowledge about general teaching principle (such as academic learning demand of time or teaching in small groups); and knowledge and skills related to classroom and knowledge management, as well as beliefs about the educational purposes.

Mishra and Koehler (2006) referred that GPK “... is deep knowledge about the processes and practices or methods of teaching and learning and how it encompasses, among other things, overall educational purposes, values, and aims" (pp. 1026-1027). GPK is a generic form of knowledge implied in all the subjects learned by the students, classroom management, development of the class' plan, and the student's evaluation. GPK includes knowledge regarding the techniques or methods that the teacher will use in the classroom; the nature of the audience; and the strategies to assess the student's understanding. A teacher with deep pedagogical knowledge understands how students build knowledge, obtain skills, and develop positive mental habits and attitudes toward learning. Therefore, acquiring pedagogical knowledge requires understanding cognitive, social, and learning developmental theories, as well as learning how to apply them with the students in the classroom (Mishra and Koehler, 2006).

Voss et al. (2011) provided a broader definition related to GPK, under General Pedagogical/Psychological Knowledge. After studying different school learning models, Voss et al. (2011) found that "there is agreement across models that students" learning takes place in a classroom setting; accordingly, the individual learning process is never isolated but always situated in the social environment of a given class" (p. 953).

This finding implies two main challenges: First, teachers must know how to organize and manage the classroom, as well as keeping the group of students doing their tasks (classroom management); and second, teachers must be familiar with a series of teaching methods and must know how to combine them, taking into consideration that they will work with different students. Teachers must learn how to assess the students' performance, according to their learning goals and to adapt their teachings to the individual student's needs. Far beyond these classroom-related aspects, the characteristics of every individual student determine their learning success in any given class.

Therefore, psychological aspects, such as general cognitive skills; motivational and affective characteristics; and, previous knowledge play important roles. Students differ in these input characteristics and teachers need to know how to deal with this heterogeneity. According to Voss et al. (2011), another relevant aspect of teachers' knowledge is their understanding about the learning processes and individual characteristics. To create strong learning opportunities, a teacher must have profound knowledge of all these general aspects.

GPK is the core knowledge of teachers; therefore, many countries include GPK within their teachers' educational curricula. GPK is also known as educational background, teaching methods, general pedagogy, and educational psychology, among others (König et al., 2011; 2014). The name delimits the field of action of GPK, and although all the given names describe the GPK as generic, they included different components (Shulman, 1987; Grossman, 1990; Borko and Putnam, 1996; Garrahy et al., 2005; Mishra and Koehler, 2006; König et al., 2011; Voss et al., 2011; König, 2014). “The opportunities to learn implemented in these components of teacher education may be very diverse, too, not only within one country (e.g., in the United States) but also across countries" (König et al., 2011. p. 189). According to König (2014) "in the US, two broad labels - educational foundations and teaching methods - are needed to cover what may be labeled as general pedagogy in others countries..." (p. 77) and state that "also in Germany the theoretical underpinnings of general pedagogy are provided by educational psychology, sociology 
of education, and history of education on the one hand and general didactics on the other hand" (p. 77).

\section{GPK's Categories}

Gatbonton (1999; 2008), Mullock (2006), and Akbari and Tajik (2009), when they document the teachers' GPK they construct the GPK categories, understanding categories as a set of pedagogical thought units (PTUs) with common themes. For example, the "Student Knowledge" category includes the pedagogical thoughts related to personality characteristics, abilities, and student needs. Each category has a definition provided by the researcher who first documents it, for example, Gatbonton (2008) refers to the affective category as: Short text or ideas (PTUs) dealing with teachers' feelings about the students and the class as well as teachers' concerns about making the students feel comfortable, relaxed, interested, motivated, and not embarrassed (e.g., "I wanted them to get interested in the pictures").

Gatbonton (1999) conducted her research in Canada with experienced teachers of English as a second language (ESL) where she found 21 categories (Table 1). In 2008, Gatbonton conducted a different study with novice ESL teachers in which she found 20 of the categories reported in her 1999 study, with "name verification" missing.

Mullock (2006) in Australia performed a study with English as Second Language (TESOL) teachers where she reported
24 categories and introduce three new categories: Curriculum Fit, Material Comment, and Institution Comment. Akbari and Tajik (2009) also reported a study performed in Iran where they find 24 categories that included those reported by Gatbonton (2008) and by Mullock (2006)

The categories of GPK found in different research works (Akbari and Tajik, 2009; Mullock, 2006; Gatbonton, 1999; 2008) are gathered in Table 1.

The main GPK categories with the highest frequencies are defined as (Gatbonton, 2008):

- Language management: PTUs dealing with language the students are and should be exposed to Language Input during the lesson and dealing with the language the students produced (Student Output)

- Procedure check: PTU sets concerned with instructional matters

- Knowledge of Students: PTUs dealing with students' personalities, their likes and dislikes, beliefs, mode of working, cultural background, etc.

- Affective: Defined above

- Note student behavior: PTUs concerned with noting students' physical behavior in class and their reactions toward the teacher, peers, and tasks given to them

- Progress review: PTUs dealing with whether students were or were not on task, were or were not making progress

Table 1: Categories of GPK

\begin{tabular}{|c|c|c|c|c|c|c|}
\hline \multirow[t]{2}{*}{ Categories } & \multicolumn{2}{|c|}{ Akbari (2009) } & \multirow[t]{2}{*}{ Mullock (2006) } & \multicolumn{2}{|c|}{ Gatbonton (1999) } & \multirow[t]{2}{*}{ Gatbonton (2008) } \\
\hline & (G1) & (G2) & & (G1) & (G2) & \\
\hline Language management & 40 & 19 & 25 & 18 & 22 & 12 \\
\hline Procedure check & 10 & 10 & 10 & 6 & 11 & 11 \\
\hline Knowledge of students & 7 & 8 & 21 & 14 & 7 & 10 \\
\hline Affective & 4 & 9 & 5 & 6 & 6 & 8 \\
\hline Note student behavior & 7 & 8 & 7 & 10 & 3 & 13 \\
\hline Progress review & 6 & 5 & 7 & 6 & 10 & 7 \\
\hline Self-know & 5 & 20 & 4 & 5 & 3 & 4 \\
\hline Decisions & 1 & 3 & 2 & 7 & 6 & 6 \\
\hline Beliefs & 1 & 2 & 2 & 6 & 8 & 7 \\
\hline Time management & 3 & 3 & 4 & 3 & 3 & 2 \\
\hline Past experience & 1 & 4 & 1 & 3 & 2 & 2 \\
\hline Group work & 2 & 2 & 2 & 2 & 2 & 1 \\
\hline Content & 2 & $<1$ & 3 & 4 & 3 & 2 \\
\hline Self-critic & $<1$ & $<1$ & 3 & 3 & 3 & 6 \\
\hline Curriculum fit & 0 & 0 & $<1$ & - & - & - \\
\hline Materials comment & 2 & 1 & 2 & - & - & - \\
\hline Institution comment & 0 & $<1$ & 1 & - & - & - \\
\hline Level check & 2 & $<1$ & 1 & $<1$ & 3 & 1 \\
\hline Problem check & 2 & $<1$ & $<1$ & 3 & 2 & 2 \\
\hline Comprehensibility & 2 & 2 & $<1$ & 1 & 2 & 3 \\
\hline Probe prior knowledge & $<1$ & $<1$ & $<1$ & $<1$ & $<1$ & $<1$ \\
\hline Name check & $<1$ & $<1$ & $<1$ & 1 & $<1$ & - \\
\hline Post active & - & - & 0 & & - & - \\
\hline Planned acts & $<1$ & 1 & $<1$ & 2 & 2 & $<1$ \\
\hline
\end{tabular}

Bold text is used to mark categories with frequencies $>3 \%$. Akbari and Gatbonton's research works present two groups differentiated by Code G1 and G2. GPK: General pedagogical knowledge 
- Self-know: PTUs concerned with teachers' comments about themselves that were not self-criticizing (p. 181)

\section{GPK's Domains}

According to Gatbonton (1999) and Mullock (2006), the domains of GPK are derived from the contents of the different categories defined above. Each domain gathers a set of GPK related to a part of the teaching-learning process.

The conceptualization of GPK by Voss et al. (2011) includes the most important aspects mentioned by the above authors and stands out from them for presenting all the definitions:

- Classroom management. Teachers must know how to organize and manage the classroom and keep the groups of students doing their tasks

- Teaching methods. Knowledge about teaching-learning methods and how to orchestrate them

- Classroom assessment. It involves teachers assessing students' progress toward their goals and adapt in their teaching to the individual needs of their students

- Learning processes. It refers to knowledge about psychological aspects, such as general cognitive skills, motivational, and affective characteristics and prior knowledge of students, which play an important role in the learning process

- Individual characteristics: Teacher needs to know how to handle classrooms with students having heterogeneous learning abilities. (p. 953)

\section{METHODOLOGY}

\section{Sample}

To teach at the high school level in Mexico, it is enough to have a degree in the discipline that must be taught; it is not compulsory to have participated in any teacher training program. All chemistry teachers of one high school were invited to participate in the first phase of the research, 18 teachers filled in questionnaires to collect information about their academic education, teaching experience, and their perceptions of the teaching process in the classroom.

A questionnaire was designed and covered participants' understanding of informed consent in this research, their interest in continuing to participate in it, and the research goal of it. The teachers participating in the case study are volunteer and were selected based on the results of the questionnaires and their interest in continuing to participate in the research.

Most teachers were not willing to be filmed in their classes, so, of those who were, three were chosen. We purposefully selected three teachers based on their comparability. These teachers are comparable in characteristics (Table 2) such as a Bachelor's degree related to chemistry, 10-15 years of teacher experience, and that work in the same institution; however, they have different level of formal teaching education.

In this study, to describe the pedagogical knowledge that chemistry teachers used (instead of describing directly the teachings), we chose a phenomenographic approach (Marton, 1986; Richardson, 1999). A video stimulated recall technique was used to identify and examine teachers' thoughts and decisions, as well as the reasons for driving their behavior. "Video stimulated recall is an effective technique for identifying and examining teachers' thoughts and decisions, and the reasons for acting as they do" (Reitano, 2006. p. 2).

This technique allows teachers to reflect and review the taped scenes at any time. Watching the videotapes can help collecting specific evidence whenever necessary and allows teachers to decide by themselves where to focus, among other benefits. There will never be full access to the "black box," but if the complimentary interview to the video is carried out as soon as possible after the recording, the interruption of the teacher's cognitive processes will be reduced (Reitano, 2006).

\section{Data Collection}

Each lesson resulted in one video recording with focus on the teacher action trough the lesson. The teachers watched about 50 min of their video, and the voice recordings were obtained while teachers recall aloud what they were thinking while they were teaching.

Their verbal recollections of those 45-50 min, out of an 80-90-min module, were the basis for this research work (Gatbonton, 1999; 2008). The analysis segment included three 15-min clips: At the beginning, in the middle, and at the end of the lesson. Each voice recording session lasted $2.5 \mathrm{~h}$ at the most. To guarantee the validity of the experimental data, the transcriptions were cross-checked and amended, when necessary, by the research team.

\section{Measures and Data Analysis}

Each audio recording was documented as written data through accurate transcripts that were submitted to a qualitative analysis to obtain the categories and domains of pedagogical ideas that were involved (Gibbs, 2012). This was a five-step procedure: Segmenting and labeling, category establishment, category definition (when needed), data selection, and selection of pedagogical knowledge domains suggested by the categories (Gatbonton, 1999).

The transcripts were read several times until the segmentations and the labeling of the PTUs were identified and converged. The PTUs are analytical units, or short text segments obtained from segmenting the transcribed texts (Gatbonton, 1999; 2008), for instance, "I tried to integrate a new student into the group" (Teacher Atziri [TA]).

The PTUs were grouped in subcategories and afterward, we compared them with the categories reported with the theoretical framework to construct the categories of our research work. All subcategories were analyzed and labeled with the category. About $84.5 \%$ of the subcategories found a direct match with one of the categories, and there were $15.5 \%$ of the subcategories that did not match any of the categories; therefore, new categories were proposed: 


\begin{tabular}{|c|c|c|c|c|c|}
\hline Teacher's pseudonym & Woman/man & Age & Bachelor's degree & Other studies & Years of teaching experience \\
\hline Atziri & Woman & 45 & $\begin{array}{l}\text { Bachelor's degree in food } \\
\text { science }\end{array}$ & $\begin{array}{l}\text { Diploma in science teaching } \\
\text { master in teaching }\end{array}$ & 14 \\
\hline Balam & Man & 48 & $\begin{array}{l}\text { Bachelor's degree in } \\
\text { pharmaceutical chemistry }\end{array}$ & $\begin{array}{l}\text { Diploma in chemistry } \\
\text { teaching }\end{array}$ & 15 \\
\hline Canek & Man & 35 & $\begin{array}{l}\text { Bachelor's degree in } \\
\text { Chemical Engineering }\end{array}$ & & 10 \\
\hline
\end{tabular}

- Applying learned concepts and abilities: PTUs that refer to activities aimed at the application of the concepts or abilities developed by students ("now you are going to make your representation;" and "the homework is for them to exercise").

- Assessment: PTUs that address aspects of the evaluation of learning objectives achieved by students ("Usually, I schedule the evaluations with a tentative date;" "you must specify the contents that will be evaluated, this is important, I even put a note for them").

- Student-student interaction: PTUs that deal with the types of relationships that arise between students ("sometimes they get a better understanding when they show the work they did to their classmates").

To improve the validity of the PTUs classification in the corresponding categories, a sample of this classification was sent to a second researcher and to each teacher, including the categories' definition. This analysis shows how they concur in at least $95 \%$ of the labeled segments.

Finally, we classified the categories of pedagogical knowledge within the domains of pedagogical knowledge, according to the conceptualization of Voss et al. (2011).

\section{FINDINGS AND DISCUSSION}

This section shows the results of our research work with the participating teachers: Atziri, Balam, and Canek.

\section{Atziri}

Table 3 shows the categories of GPK corresponding to TA. The PTUs expressed by this teacher were grouped into 12 categories of GPK. The category with the highest number of PTUs is comprehension check, which refers mainly to the teacher's concern in case there was an understanding by the students, "verifying that students are understanding what is being taught." This category groups just over $25 \%$ of the PTUs registered in the interview.

Other categories that stand out are affective (11\%) "I tried to integrate a new student into the group," aid comprehension (11\%) "I tried to be explicit," and content (11\%) "I make this cut to highlight what are the most central ideas." The first two categories (Affective and Aid Comprehension) are focused on student support. This is manifested in the statements that express an interest in students feeling comfortable and motivated in class, and in those expressing the importance of

\begin{tabular}{|c|c|c|c|c|c|}
\hline \# & $\begin{array}{l}\text { Categories (\# } \\
\text { PTUs) }\end{array}$ & $\%$ & \# & Categories (\# PTUs) & $\%$ \\
\hline 1. & $\begin{array}{l}\text { Comprehension } \\
\text { check (28) }\end{array}$ & 25.7 & 7. & $\begin{array}{l}\text { Note student behavior } \\
\text { and reactions ( } 8 \text { ) }\end{array}$ & 7.3 \\
\hline 2. & Affective (12) & 11 & 8. & Procedure check (6) & 5.5 \\
\hline 3. & $\begin{array}{l}\text { Aid comprehension } \\
\text { (12) }\end{array}$ & 11 & 9. & $\begin{array}{l}\text { Student-student } \\
\text { interaction* (4) }\end{array}$ & 3.7 \\
\hline 4. & Content (12) & 11 & 10. & $\begin{array}{l}\text { Language management } \\
\text { (3) }\end{array}$ & 2.7 \\
\hline 5. & $\begin{array}{l}\text { Materials comment } \\
\text { (10) }\end{array}$ & 9.2 & 11. & Name check (3) & 2.7 \\
\hline 6. & $\begin{array}{l}\text { Applying learned } \\
\text { concepts and } \\
\text { abilities * }(10)\end{array}$ & 9.2 & 12. & $\begin{array}{l}\text { Knowledge of Students } \\
\text { (1) }\end{array}$ & $<1$ \\
\hline
\end{tabular}

students understanding the main ideas being taught. Content refers to what students are learning as well as the knowledge they must have mastery; therefore, this category of GPK is at the limit that differentiates it from PCK.

In summary, the teacher demonstrated the knowledge that refers to classroom processes, such as class management and teaching methods. This was evidenced by the importance she refers to the students' understanding throughout the entire lesson; however, the teacher did not mention the use of a specific teaching method, nor did it refer specifically to the assessment process. Atziri focused on knowledge about student learning processes, especially in their motivational aspect, nevertheless, it did not express ideas related to the characteristics of the students and presented few PTUs that addressed verbal cues and name verification.

\section{Balam}

Table 4 shows the categories of GPK corresponding to teacher Balam (TB). The PTUs manifested by Balam can be grouped into 16 categories. The three highest categories are assessment with almost $19 \%$, affective (16.3\%), and the procedure check $(14.6 \%)$. The above information gives us an indication that this teacher had as a central assessment concerned students' culture of evaluation, coevaluation, and self-evaluation being promoted. It also indicated Balam's interest in making students feel comfortable, relaxed, involved, motivated, and not ashamed, "Try to encourage them to feel comfortable in class and make them feel better people, not just better students; it is also important to recognize them." There are also several 


\begin{tabular}{|c|c|c|c|c|c|}
\hline$\#$ & Categories (\# PTUs) & $\%$ & \# & Categories (\# PTUs) & $\%$ \\
\hline 1. & Assessment* (23) & 18.7 & 9. & Comprehension Check (5) & 4.0 \\
\hline 2. & Affective (20) & 16.3 & 10. & Materials Comment (5) & 4.0 \\
\hline 3. & Procedure check (18) & 14.6 & 11. & Applying learned concepts and abilities * (5) & 4.0 \\
\hline 4. & Group work (10) & 8.1 & 12. & Student-Student Interaction* (5) & 4.0 \\
\hline 5. & Time management (9) & 7.3 & 13. & Decisions (4) & 3.2 \\
\hline 6. & Progress review (6) & 4.8 & 14. & Self-Critic (1) & $<1$ \\
\hline 7. & Language management (5) & 4.0 & 15. & Aid Comprehension (1) & $<1$ \\
\hline 8. & Planning (5) & 4.0 & 16. & Content (1) & $<1$ \\
\hline
\end{tabular}

* New category. GPK: General pedagogical knowledge

PTUs related to different aspects of the instruction, "First, I will give the basis of how the session is going to take place."

On a second level, two categories of GPK stand out Group Work (8.1\% PTUs) and time management (7.3\% PTUs). The teacher highlighted the benefits of group work and the role that the teacher should have in this environment, "The teamwork, the product is the same for all team members."

In summary, TB showed knowledge about assessment and classroom management. He also referred to teaching methods and processes in the classroom, particularly about collaborative work and time management, and highlighted the importance of knowledge about the learning process and heterogeneity of his students by mentioning their motivational and emotional characteristics. However, this teacher did not explicitly express much interest in his own defects and errors; on ways to help students' memory and understanding; nor about what the students were learning or what they should have mastery.

\section{Canek}

Table 5 shows the categories of GPK corresponding to teacher Canek (TC). The categories affective and knowledge of students stand out with nearly $18 \%$ of the total UPPs expressed by this teacher. This indicated that TC took care that students felt comfortable, relaxed, interested, motivated, and not ashamed. "They perceive that you care" as well that he stood out concerning the personalities of the students, their likes and dislikes, beliefs, ways of working, and cultural backgrounds. TC stated, "With the students that I pay more attention to are those who have difficulty performing the exercises and with those who do not come to class regularly."

On the second level, the categories Procedure Check (11\%), Aid Comprehension (14\%), and Materials Comment (12\%) stood out. These addressed: Aspects of teaching, "There are times when I prefer that they first pay attention to the explanation on the board and then write down;" the ways to help students' memory and understanding, "Visual help to constantly show the basic or most important knowledge;" and, the teaching resources used by the teacher to support his teaching practice, "as many colors as I can use ..., they already have their copies and there are the exercises."

In summary, the knowledge expressed by Canek was mainly directed toward the heterogeneity of the students. The teacher emphasized the psychological aspects mainly the general cognitive abilities and the motivational and affective characteristics. The knowledge of the classroom processes expressed by the teacher referred to aspects of organization and management of the class and to involve students in the task. This teacher showed the lowest number of PTUs, grouped into the smallest number of pedagogical knowledge categories.

\section{Chemistry Teachers' GPK Categories}

There were 19 categories found in this research work, the quantity of PTUs mentioned by the participating teachers, in each category are concentrated in Table 6 .

The subcategories allowed us to determine the corresponding category and to create new categories when needed. Three of them were new category proposals applying learned concepts and abilities, assessment, and student-student interaction.

We found eight categories (1-8) that presented percentages above $10 \%$ where the three teachers concentrated most of their GPK: Affective, comprehension check, procedure check, aid comprehension, materials comment, assessment, knowledge of students, and content. Three of them were among the highest frequencies also reported in the Gatbonton and Mullock studies: Affective, procedure check, and knowledge of students.

Gatbonton and Mullock reported only six of these eight categories. The differences could be explained due to the contexts of each study. Gatbonton does not mention the institution's conditions within the classroom management domain characterized by Mullock as institutional policy's knowledge (delays, and late enrollment), and learning/teaching facilities (size, shape, furniture, and layout). In Gatbonton's research work, teachers received formal training as teachers; their students were adults ( $22-45$ years-old students) enrolled in courses especially designed for that research work. In contrast, this study included chemistry teachers who have not all received teaching formal education, their students were teenagers, and the courses were the regular courses of the participating teachers.

These differences came to the fore from the results of the transcriptions of the teachers' recall memories, and they are considered fundamental for this study, as they might point to different expressions of the GPK. In this research, the 
outstanding categories reflect teachers' concern to maintain a good learning environment, where students feel well, comfortable, and at ease, "I try to stimulate them to feel comfortable in class, to make them feel better persons, not only better students" (TB). This can help them to learn more effectively, "I tried to be more explicit" (TA).

TC, who had less teaching experience, referred to some negative aspects of the students' behavior, for example, "They are always expecting instructions from the teacher. They do not start working by themselves; I take out my tablet, my pencil, my notes, while they just wait." According to Gatbonton (2008), this comment may show a lack of confidence as a teacher; however, it is important to be more aware of the negative signs coming from the students.

Teachers gave their opinion about the support material, "I need the computer to project some information" (TC), as well as about the assessment in which the TB PTUs are the highest of the three teachers, "So they know what we are going to assess them on; we tell them which parts will be examined. I maintain

\begin{tabular}{|c|c|c|c|c|c|}
\hline$\#$ & Categories (\# PTUs) & $\%$ & \# & Categories (\# PTUs) & $\%$ \\
\hline 1. & Affective (21) & & 6. & Self-critic (8) & \\
\hline 2. & $\begin{array}{l}\text { Knowledge of students } \\
(20)\end{array}$ & & 7. & Comprehension check (7) & \\
\hline 3. & Aid comprehension (16) & & 8. & Name check (6) & \\
\hline 4. & Material comments (14) & & 9. & Assessment* (6) & \\
\hline 5. & Procedure check (13) & & 10. & $\begin{array}{l}\text { Applying learned concepts } \\
\text { and abilities * (3) }\end{array}$ & \\
\hline
\end{tabular}

*New category. GPK: General pedagogical knowledge three levels of assessment" (TB).

Beyond the outstanding categories, in the remaining categories, teachers expressed how much they would like their students to apply their teachings. "They will work by themselves. I think they have enough basis to do this drill by themselves" (TA). Including students' interaction, "Sometimes they understand better when they work among themselves" (TB).

Although there are differences between this research work and these previous researches, we also found that in general the GPK of chemistry teachers was similar to GPK of other teachers of humanities.

A question arises from the similarity of these results. How can TC have similar GPK similar to the other teachers when he did not receive formal teacher training? Calderhead and Robson (1991) may have an answer for this. After conducting a study with teachers under training, they found that these teachers had very particular images of teaching, mostly derived from their experiences in the school, as students, which sometimes had a lot of impact on their interpretation of class and classroom practice.

The three teachers presented some categories with high frequencies. Even though when the participating teachers had different teaching training, their groups of students were different and these teachers had been teaching between ten to 15 years; they had enough opportunities to work within the same educational sub-system, following the same educational model. This can be explained with Mishra and Koehler (2006) conceptualization of GPK “... is deep knowledge about the processes and practices or methods of teaching and

\begin{tabular}{|c|c|c|c|c|c|c|}
\hline Category & Teacher A \% & Teacher B \% & Teacher C \% & Total (\%) & $\begin{array}{l}\text { Categories from } \\
\text { other studies }\end{array}$ & $\begin{array}{l}\text { Categories found } \\
\text { in this study }\end{array}$ \\
\hline Affective & 11 & 16 & 18 & $53(15)$ & $\mathrm{x}$ & \\
\hline Comprehension check & 26 & 4 & 6 & $40(11)$ & $\mathrm{x}$ & \\
\hline Procedure check & 6 & 15 & 11 & $37(10)$ & $\mathrm{x}$ & \\
\hline Aid comprehension & 11 & 1 & 14 & $29(8)$ & $\mathrm{x}$ & \\
\hline Materials comment & 9 & 4 & 12 & $29(8)$ & $\mathrm{x}^{\mathrm{o}}$ & \\
\hline Assessment & 0 & 19 & 5 & $29(8)$ & & $\mathrm{x}$ \\
\hline Knowledge of Students & 1 & 0 & 18 & $21(6)$ & $\mathrm{x}$ & \\
\hline Applying learned concepts and abilities & 9 & 4 & 3 & $18(5)$ & & $\mathrm{x}$ \\
\hline Content & 11 & 1 & 0 & $13(4)$ & $\mathrm{x}$ & \\
\hline Group work & 0 & 8 & 0 & $10(3)$ & $\mathrm{x}$ & \\
\hline Self-critic & 0 & 1 & 7 & $9(2.5)$ & $\mathrm{x}$ & \\
\hline Time management & 0 & 7 & 0 & $9(2.5)$ & $\mathrm{x}$ & \\
\hline Note student behavior & 7 & 0 & 0 & $8(2)$ & $\mathrm{x}$ & \\
\hline Name check & 3 & 0 & 5 & $9(2.5)$ & $\mathrm{x}$ & \\
\hline Student-student interaction & 4 & 4 & 0 & $9(2.5)$ & & $\mathrm{x}$ \\
\hline Language management & 3 & 4 & 0 & $8(2)$ & $\mathrm{x}$ & \\
\hline Planning & 0 & 4 & 0 & $5(1.5)$ & $\mathrm{x}$ & \\
\hline Progress review & 0 & 5 & 0 & $6(1.5)$ & $\mathrm{x}$ & \\
\hline Decisions & 0 & 3 & 0 & $4(1)$ & $\mathrm{x}$ & \\
\hline
\end{tabular}

$\mathrm{x}^{\mathrm{o}}$ category introduced by Mullock (2006). GPK: General pedagogical knowledge 
learning and how it encompasses, among other things, overall educational purposes, values, and aims" (p. 1026-1027) in with the educational purposes can be link to the education sub-systems and to different institutions.

Gatbonton (2008) found similar results with experienced and new teachers regarding the GPK categories. According to the author, these results suggested that from their early developmental stages, new teachers had already acquired or were about to obtain many skills that were expected from experienced teachers. Lortie (1965) suggests that all of us have been observing our teachers at school, and from this "learning by observation" (Gatbonton, 2008. p. 172), we know a lot about teachers' behavior.

Although, as teachers gain experience in teaching, they tend to organize their knowledge about cases and experiences found, which could lead to more elaborate and coherently organized knowledge structures (Kraus et al., 2008). This is in accordance with what Thiessen (2000) mentions that the final phase of teacher training is the most promising for the teacher since it includes a work that implies the interrelated use of practical knowledge (routines, procedures, and processes) and propositional knowledge (theories and concepts based on the discipline, pedagogical principles, and specific propositions of the situation).

\section{Domains of GPK}

According to Gatbonton (1999), "The pedagogical knowledge deduced from the teachers' verbal recollections reflected many of the pedagogical points stressed in teacher education" (p. 45). Gatbonton concluded from her research on ESL teacher training and teaching from the content of articles, books, and manuals, that "More often than not, these textbooks contain chapters dedicated to methodological or procedural issues, to exposing students to good quality input, to improving student output, and to evaluating and monitoring student progress" (p.45).

About the methodology to obtained the GPK domains, Mullock (2006) stated that "in the next stage of the analysis, the transcripts and reported PTUs were re-examined and abstracted into domains of pedagogical knowledge" (p. 56), and adds that "Gatbonton (1999) provided a summary list of all teachers' teaching thoughts for the six domains, and these lists were drawn on in the current study" (p. 56).

The domains GPK conceptualization by Voss et al. (2011) include all of the definitions and also includes the most important aspects mentioned Gatbontton and Mullock researches. In this last section, we analyzed the GPK's domains inferred from the GPK categories, based on Voss et al. (2011) conceptualization.

\section{Teaching methods}

All the participating teachers spoke about the importance of class management, teaching, and learning methods, and the importance of using and combining them, but only TB spoke about group learning. Some examples of PTU in this domain are "They must understand that they can learn from each other, not only individually."
Regarding TC, it is easy to understand that he does not have any theoretical basis to talk about the subject. However, the case of TA, who has a Master's degree in teaching, can serve as an example of what experts say regarding the fact that theoretical education is not always set into practice.

\section{Classroom assessment}

Teachers need to assess the students' progress toward their goals, to adapt their teaching to their individual needs. Classroom assessment was mentioned under assessment category by TC and by TB. Some examples of PTU in this domain are "We must tell them concretely which areas are going to be assessed. It is so important, that I posted the information" (TB) and "They should have a clear idea of what I am going to assess; what I want to find out; how they are doing; if they know little, a lot, or nothing at all" (TC). Indirectly, the three teachers mentioned this aspect under applying learned concepts and abilities category.

It is important to mention that Gatbonton and Mullock do not refer directly to classroom assessment, they refer to the progress in the class in "Supervision of the students' progress in class" that includes knowing how and when we need to submit proof that students have understood the instructions, and if they are focused on their tasks and making progress. Therefore, progress' review falls within the classroom management domain in this research work.

\section{Classroom management}

This domain of GPK included ten of the nineteen categories: Comprehension Check, Procedure Check, Aid Comprehension, Materials Comment, Note Student Behavior, Student-student Interaction, Time management, Planning, Progress Review, and Decisions. Some examples of PTU in this domain are "When I realized that they did not understand..." (TA) and "first we set the basis for the development of the session" (TB).

The categories distribution is not uniform among teachers. TC has PTUs in only four categories; TA has PTUs in six categories and TB, the most versatile teacher has PTUs in nine of ten categories, out of which four refer to: Time Management, Planning, Progress Review, and Decisions. The teacher (TC) without formal pedagogical education shows less versatility in their GPK of classroom management. TC in our study recorded PTUs only within the categories of Comprehension Check, Procedure Check, Aid Comprehension, and Materials Comment.

Regarding the other two teachers with similar teaching experience and formal pedagogical education, we must ask ourselves why the teacher with only a diploma in teaching has a broader range of class management possibilities than the teacher who, besides having a diploma in teaching, also completed a Master's degree in teaching. Kunter et al. (2013) express that to learn more about the characteristics of a good teacher, it is necessary to do more research on cognitive aspects, professional knowledge, believes, as well as on the motivational and self-regulating variables of teachers. 
The importance of this GPK domain coincides with the results of an international research work conducted by König et al. (2011). During their literature review on GPK, they found that giving instructions and class management are two essential skills that teachers most have in almost every country.

\section{Learning processes}

Regarding the psychological aspects such as general cognitive skills, motivational, and affective characteristics, as well as previous student's knowledge that plays such an important role in the learning process, the three teachers talked only about the affective aspects from or toward the students. Some examples of PTU in this domain are "I wanted him to participate more" (TA), "We have to give them more personal attention" (TB) and "Positive reinforcement enhances empathy" (TC).

\section{Individual characteristics}

Students have different characteristics when they reach the classroom and teachers must know how to manage such heterogeneity. However, teachers talked very little about this topic during the interviews. It is interesting to note that TC, with no formal teaching education, is the one who spoke more about the knowledge of students and Name Check categories, as crucial points to make his teaching effective. Although this teacher is not new, we may think that he is a new vis-à-vis formal teaching education (Gatbonton, 2008). An example of PTU in this domain is "He is quite able to do it, but he misses classes and that is why it is difficult for him" (TC).

The domains of GPK found in this study (Table 7) correspond to the domains published by Voss et al. (2011) who have reached a comprehensive definition of the domains using a theoretical approach, and therefore, we are using their work as our main reference.

Table 7 shows that the pedagogical knowledge domains found in this research concurred with the domains reported in the literature. In summary, the participating chemistry teachers showed GPK about classroom processes, about classroom management, even when their knowledge on teaching methods and classroom assessment was rather poor. Regarding the students' heterogeneity, teachers showed some knowledge on the factors that take part in the students' learning processes, especially regarding affective aspects. Nevertheless, their knowledge about the individual characteristics of students is limited.

\begin{tabular}{lccc}
\hline Table 7: Domains of GPK of teachers TA, TB, and TC & \\
\hline $\begin{array}{l}\text { Domains of general pedagogical knowledge Voss } \\
\text { et al. (2011) }\end{array}$ & TA & TC \\
\hline Teaching methods & - & $\sqrt{ }$ & - \\
Classroom assessment & - & $\sqrt{ }$ & $\sqrt{ }$ \\
Classroom management & $\sqrt{ }$ & $\sqrt{ }$ & $\sqrt{ }$ \\
Learning processes & $\sqrt{ }$ & $\sqrt{ }$ & $\sqrt{ }$ \\
Individual characteristics & - & - & $\sqrt{ }$ \\
\hline
\end{tabular}

TA: Teacher Atziri, TB: Teacher Balam, TC: Teacher Canek. GPK: General pedagogical knowledge

\section{CONCLUSION}

The understanding of the teaching process and the way in which teachers acquire their experience in this process is only possible if knowledge, theories, and beliefs about teaching and learning are taken into consideration. This work was carried out with the assumption that it is possible to access the knowledge pattern about teaching and learning "General Pedagogical Knowledge" that teachers use while teaching. As a premise when teachers work to promote learning in the classroom, they are guided by mental acts that have been shaped by the knowledge and beliefs about teaching and learning that they have accumulated over the years, either intuitively, and/or formally. Therefore, if these thoughts can be documented and analyzed, it is possible to make inferences about the knowledge that lies behind them.

This research was focused on assessing of the GPK in chemistry teachers while most researchers have focused their studies on the GPK of teachers of humanities subjects. There are coincidences with the results obtained from other studies in humanities and this research work conducted in sciences. The pedagogical thoughts of the teachers comprised 19 categories, and the three teachers express most of their GPK in eight categories.

This research work showed that the participating teachers had GPK, but their uniqueness resulted in their different expressions of it. The participating chemistry teachers showed GPK about classroom processes, especially about classroom management, although they spoke very little about the teaching methods and classroom assessment during the interviews. Regarding the students' heterogeneity, teachers showed to be familiar with the factors that have an impact on the students' learning, for example, with the affective aspects; however, paradoxically, they express scarce knowledge on the individual characteristics of their students.

With this research work, we conclude that teachers possess GPK that they use in teaching, regardless of their years of experience and if they teach humanistic or scientific subjects with different levels of competencies and different targets. Each teacher will express a different profile of GPK, and it is related to their institutional context. Therefore, teachers from the same institutional context have in common a set of categories with higher frequencies.

Thanks to the differences that we found, our research work contributed to identify three new categories of GPK that was not reported by literature: Applying learned concepts and abilities, student-student interaction, and assessment. This work contributed with information that can lead to future research works with larger numbers of teachers and other disciplines within the fields of science and humanities, under diverse contexts.

\section{REFERENCES}

Akbari, R., \& Tajik, L. (2009). L2 teachers' pedagogic knowledge base: A comparison between experienced and less experienced practitioners. Australian Journal of Teacher Education, 34(6), 52-73.

Baumert, J., Kunter, M., Blum, W., Brunner, M., Voss, T., Jordan, A., 
Klusmann, U., Krauss, S., Neubrand, \& M., Tsai, Y. (2010). Teachers' mathematical knowledge, cognitive activation in the classroom, and student progress. American Educational Research Journal, 47(1), 133180 .

Borko, H., \& Putnam, R.T. (1996). Learning to teach. In: Berliner, D.C., \& Calfee, R.C., (Eds.), Handbook of Educational Psychology. United States: Simon and Schuster Macmillan-Prentice Hall International. pp. 673-708.

Calderhead, J., \& Robson, M. (1991). Images of teaching: Student teachers' early conceptions of classroom practice. Teaching and Teacher Education, 7(1), 1-8.

Garrahy, D.A., Cothran, D.J., \& Kulinna, P.H. (2005). Voices from the trenches: an exploration of teachers' management knowledge. The Journal of Educational Research, 99(1), 56-63.

Gatbonton, E. (1999). Investigating experienced ESL teachers' pedagogical knowledge. The Modern Language Journal, 83, 35-50.

Gatbonton, E. (2008). Looking beyond teachers' classroom behaviour: Novice and experienced ESL teachers' pedagogical knowledge. Language Teacher Research, 12(2), 161-182.

Gibbs, G. (2012). Qualitative Data Analysis in Qualitative Research (El Análisis de Datos Cualitativos en Investigación Cualitativa). Morata Edition, Investigación.

Grossman, P.L. (1990). The Making of a Teacher. Teacher Knowledge and Teacher Education. New York: Teachers College Press.

Guerriero, S. (2017). Teachers' pedagogical knowledge: What it is and how it functions. In: Guerriero, S., (Ed.), Pedagogical Knowledge and the Changing Nature of the Teaching Profession. Paris, France: OECD Publishing. pp. 99-118.

Guerriero, S., \& Deligiannidi, K. (2017). The teaching profession and its knowledge base. In: Guerriero, S., (Ed.), Pedagogical Knowledge and the Changing Nature of the Teaching Profession. Paris, France: OECD Publishing. pp. 19-36.

Kirschner, S., Borowski, A., Fischer, H.E., Gess-Newsome, J., \& von Aufschnaiter, C. (2016). Developing and evaluating a paper-and-pencil test to assess components of physics teachers' pedagogical content knowledge. International Journal of Science Education, 38(8), 1343-1372.

König, J., (2014). Designing an International Instrument to Assess Teachers' General Pedagogical Knowledge (GPK): Review of Studies, Considerations, and Recommendations. Available from: http://www. oecd.org/officialdocuments/publicdisplaydocumentpdf/?cote=EDU/ CERI/CD/RD\%282014\%293/REV1\&doclanguage=en .

König, J., Blömeke, S., Klein, P., Suhl, U., Busse, A., \& Kaiser, G. (2014). Is teachers' general pedagogical knowledge a premise for noticing and interpreting classroom situations? A video-based assessment approach. Teaching and Teacher Education, 38, 76-88.

König, J., Blömeke, S., Paine, L., Schmidt, W.H., \& Hsieh, F.J. (2011). General pedagogical knowledge of future middle school teachers: On the complex ecology of teacher education in the United States, Germany and Taiwan. Journal of Teacher Education, 62(2), 188-201.

König, J., Doll, J., Buchholtz, N., Förster, S., Kaspar, K., Rühl, A., Strauß, S., Bremerich-Vos, A., Fladung, I., \& Kaiser, G. (2018). General
Pedagogical Knowledge Versus Pedagogical Content Knowledge? The Structure of Professional Knowledge in Pre-Service Teachers of German, English, and Mathematics at University.

König, J., Ligtvoet, R., Klemenz, S., \& Rothland, M., (2017). Effects of opportunities to learn in teacher preparation on future teachers' general pedagogical knowledge: Analyzing program characteristics and outcomes. Studies in Educational Evaluation, 53, 122-133.

Kunter, M., Klusmann, U., Baumert, J., Richter, D., Voss, T., \& Hachfeld, A. (2013). Professional competence of teachers: Effects on instructional quality and student development. Journal of Educational Psychology, 105(3), 805-820

Lachner, A., Jarodzka, H., \& Nückles, M. (2016). What makes an expert teacher? Investigating teachers' professional vision and discourses abilities. Instructional Science, 44(3), 197-203.

Lortie, D. (1965). Schoolteachers: A Sociological Study. Chicago, Illinois: University of Chicago Press.

Marton, F. (1986). Phenomenography a research approach to investigating different understandings of reality. Journal of Thought, 21, 28-49.

Mishra, P., \& Koehler, M.J. (2006). Technological pedagogical content knowledge: A framework for teacher knowledge. Teachers College Record, 108(6), 1017-1054.

Morine-Dershimer, G., \& Kent, T. (1999). The complex nature and sources of teachers' pedagogical knowledge. In: Gess-Newsome, J., \& Lederman, N.G., (Eds.), Examining Pedagogical Content Knowledge: The Construct and its Implications for Science Education. Berlin, Germany: Springer. pp. 21-50.

Mullock, B. (2006). The pedagogical knowledge base of four TESOL teachers. The Modern Language Journal, 90, 48-66.

Peterson, D., Kromrey, J., Lewis, A., \& Borg, J. (1992). Clinical pedagogy: Defining and measuring the teaching of essential and higher order thinking skills. Journal of Personnel Evaluation in Education, 6, 57-70.

Reitano, P. (2006). The Value of Video Stimulated Recall in Reflective Teaching Practices. Alphington, Australia: Australian Consortium for Social and Political Research Incorporated.

Richardson, J.T.E. (1999). The concepts and methods of phenomenographic research. Review of Educational Research, 69(1), 53-82.

Shulman, L.S. (1986). Those who understand: Knowledge growth in teaching. Educational Researcher, 15(2), 4-14.

Shulman, L.S. (1987). Knowledge and teaching: Foundations of the new reform. Harvard Educational Review, 57(1), 1-22.

Sonmark, K., Révai, N., Gottschalk, F., Deligiannidi, K., \& Burns, T. (2017). Understanding Teachers' Pedagogical Knowledge: Report on an International Pilot Study. OECD Education Working Papers, No. 159. Paris, France: OECD Publishing.

Thiessen, D. (2000). Developing knowledge for preparing teachers: Redefining the role of schools of education. Educational Policy, 14(1) 129-144.

Voss, T., Kunter, M., \& Baumert J. (2011). Assessing teacher candidates' general pedagogical/psychological knowledge: Test construction and validation. Journal of Educational Psychology, 103(4), 952-969. 